\title{
BUDAYA ORGANISASI PESANTREN DALAM MEMBENTUK SANTRI PUTRI YANG PEDULI KONSERVASI LINGKUNGAN
}

\author{
Ah. Choiron \\ Sekolah Tinggi Agama Islam Negeri Kudus \\ ahmadchoiron55@gmail.com
}

ABSTRAK

Peran pesantren sebagai lembaga pendidikan kegamaan diharapkan mampu memberikan pengetahuan dan tata nilai Islami berkaitan dengan lingkungan. Santri baik laki-laki maupun perempuan memiliki wawasan ramah lingkungan melalui budaya organisasi yang ada di Pesantren. Unsur budaya organisasi pesantren yang telah dimanfaatkan dalam peningkatan kesadaran ekologi bagi santri putri dilakukan melaui perwujudan verbal dan perwujudan perilaku. Budaya organisasi di pesantren dalam mendorong santri putri terlibat dalam pengelolaan lingkungan terkendala oleh adanya semacam pembagian wilayah bagi santri putri dan putra dalam pengelolaan lingkungan sebagai akibat pembakuan peran di pesantren.

Kata kunci: Islamic Boarding School, Female Student, Budaya Organisasi

\section{ABSTRACT}

The role of pesantren as a religious education institution is expected to be able to provide Islamic knowledge and values related to the environment. Santri both male and female have eco-friendly insights through the organizational culture in the pesantren. The organizational culture elements of the pesantren that have been used in increasing ecological awareness for female santri are carried out through verbal manifestations and behavioral manifestations. Organizational culture in pesantren are encouraging female santri to be involved in environmental management. It is constrained by the existence of a kind of division of area for female and male students in environmental management as a result of standardizing roles in pesantren.

Keyword: Islamic Boarding School, Female Student, Organizational culture 


\section{A. Pendahuluan}

Perempuan secara potensi tidak kalah dengan laki-laki, tetapi ada beberapa hal yang sering kali menjadi penghalang bagi perempuan untuk merealisasikan semua potensinya. Penghalang itu bisa dari diri sendiri, misalnya tidak punya cita-cita tinggi, atau merasa takut gagal, atau bahkan mereka tidak mampu. Bisa dari luar dirinya, seperti paradigma para senior tentang perempuan atau pengaruh sosial budaya tentang peran perempuan dalam keluarga (Betti, 2017: 8-9).

Dilema peran domestik dan publik seringkali mengkondisikan perempuan memilih salah satu antara keluarga dan karier. Ada yang memutuskan untuk tidak menikah agar leluasa untuk berkarier. Ada yang memutuskan untuk melepaskan karier dan impian-impiannya agar dapat menjalankan tugasnya sebagai ibu dan istri dengan baik. Pada hakikatnya bahwa antara keluarga dan karier tidak harus dipilih salah satu. Karier dan keluarga bisa berjalan bersama. Malah masih ditambah lagi dengan peran dan kontribusi kepada masyarakat luas (Betti, 2017: 8-9). Persoalan perempuan sesunggunya bukan hanya domestik, non domestik atau peran gandanya seperti diatas juga peran sosial dengan keterlibatannya dalam lingkungan.

Pesantren merupakan pusat pembelajaran, dakwah dan pemberdayaan masyarakat. Sebagai lembaga pendidikan tertua di Indonesia, pesantren memainkan peran yang sangat penting dalam sejarah pendidikan (Zamakhsyari, 1982: 18). Pesantren juga memainkan peran tidak tergantikan dalam penyebaran Islam di Indonesia. Pesantren menyediakan media sosialisasi formal dimana keyakinan, normal, dan nilai-nilai Islam ditransmisikan serta ditanamkan melalui berbagai aktivitas pengajaran. Dengan kata lain, pesantren berfungsi pula sebagai pengembangan ajaran Islam dan pemelihara ortodok (Endang, 2004: 37).

Pesantren dipandang sebagai sebuah lembaga sosial dengan ciri-ciri yang khusus. Dalam proses sosialisasi tersebut, masing-masing agen sosialisasi memainkan perannya berdasar konteks posisi sosial mereka masing-masing. Sosialisasi memproduksi dan mereproduksi berbagai diskursus di pesantren. Dalam konteks wawasan gender, diskursus tersebut mencakup berbagai elemen, termasuk nilai-nilai, norma-norma, ajaran, model atau contoh perilaku, aturan, serta pesan-pesan gender lainnya (Emma, 2011: 27). 


\section{B. Pembahasan}

\section{Budaya Organisasi Pondok Pesantren}

Budaya organisasi merupakan kesepakatan bersama tentang nilai-nilai bersama dalam kehidupan organisasi dan mengikat semua orang dalam organisasi yang bersangkutan. F.E. Kast dan Rozenzweig (1974: 193) mendefinisikan budaya organisasi sebagai seperangkat nilai, kepercayaan dan pemahaman penting yang sama-sama dimiliki oleh para anggotanya. Ia menyatakan nilai-nilai atau ide-ide dan kepercayaan bahwa yang sama-sama dianut oleh para anggota itu seperti terwujud dalam alat-alat simbolis seperti mitos, upacara, cerita, legenda, dan bahasa khusus.

Edgar H. Schein (2006: 44) mendefinisikan Budaya Organisasi sebagai

A pattern of basic assumption-invented, discovered, or development by a given as it learns to cope with its problems of external adaptation and internal integrationthat has worked well enough to be considered valid and therefore, to be taugh to new members as the correct way to perceives think and fell in relation to those problems (suatu pola dari asumsi dasar -yang diciptakan, ditemukan atau dikembangkan oleh kelompok tertentu saat belajar menghadapi masalah adaptasi eksternal dan integrasi internal- yang telah berjalan cukup baik untuk dianggap valid dan oleh karena itu untuk diajarkan kepada anggota baru sebagai cara yang benar untuk persepsi, berpikir, dan berperasaan sehubungan dengan masalah yang dihadapainya.

Oleh karena itu, budaya organisasi akan menentukan apa yang boleh dan tidak boleh dilakukan oleh para anggota organisasi; menentukan batas-batas normatif perilaku anggota organisasi; menentukan sifat dan bentuk-bentuk pengendalian dan pengawasan organisasi; menentukan gaya manajerial yang dapat diterima oleh para anggota organisasi; menentukan cara-cara kerja yang tepat, dan sebagainya (Agus Suryono, 2001).

Budaya organisasi adalah salah satu aspek yang menentukan keberhasilan suatu organisasi. Salah satu konsekuensi dari budaya organisasi yang kuat adalah meningkatnya perilaku yang konsisten dari tiap individu dalam organisasi (Jesper B Sorensen, 2002). Budaya organisasi berfungsi memberikan inspirasi dan memfasilitasi interaksi yang intens antara individu dan tim yang dibutuhkan untuk membangun kompetensi organisasi.

Budaya organisasi/ perusahaan menurut Kotter dan Heskett terbentuk dalam serangkaian proses yang dapat dilihat pada gambar 1: 


\section{Manager Puncak}

Seorang atau para manager puncak dalam perusahaan yang masih baru atau muda mengembangkan dan berusaha untuk mengimplementasikaan suatu visi/filisofi dan/atau strategi bisnis.

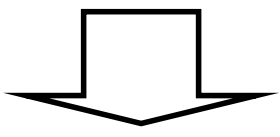

Perilaku Organisasi

Karya-karya implementasi. Orang-orang berperilaku melalui cara yang dipandu oleh filosofi dan strategi.

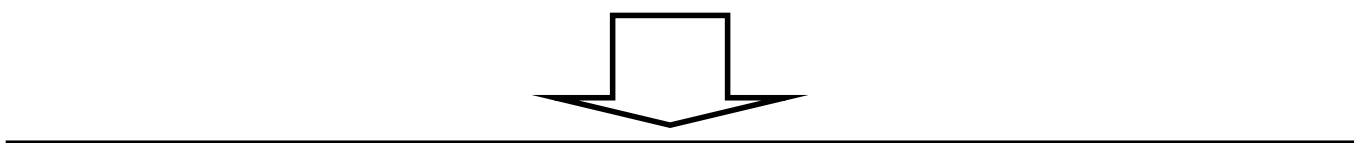

Hasil

Dipandang dari berbagai segi, perusahaan itu berhasil dan keberhasilan itu terus berkesinambungan selama bertahun-tahun

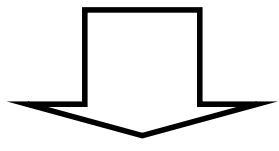

Budaya

Suatu budaya muncul, mencerminkan visi dan strategi serta pengalamanpengalaman yang dimiliki orang dalam mengimplementasikannya.

Gambar 1. Proses Terbentuknya Budaya Organisasi menurut Kotter dan Heskett (Sumber : Kotter dan Heskett, Corporate Culture and Performance, 1997)

Pada lembaga pendidikan, budaya organisasi dikembangkan dengan nilainilai yang relevan dengan semangat visi lembaga tersebut, terutama keperpihakan terhadap proses belajar sebagai misi utama. Oleh karena itu nilainilai organisasi harus diarahkan pada pelayanan belajar yang optimal bagi peserta didik sehingga mereka dapat mengembangkan potensinya secara optimal. Unsur dalam budaya organisasi di lembaga pendidikan sebagai berikut (Khofsoh, 2008): 


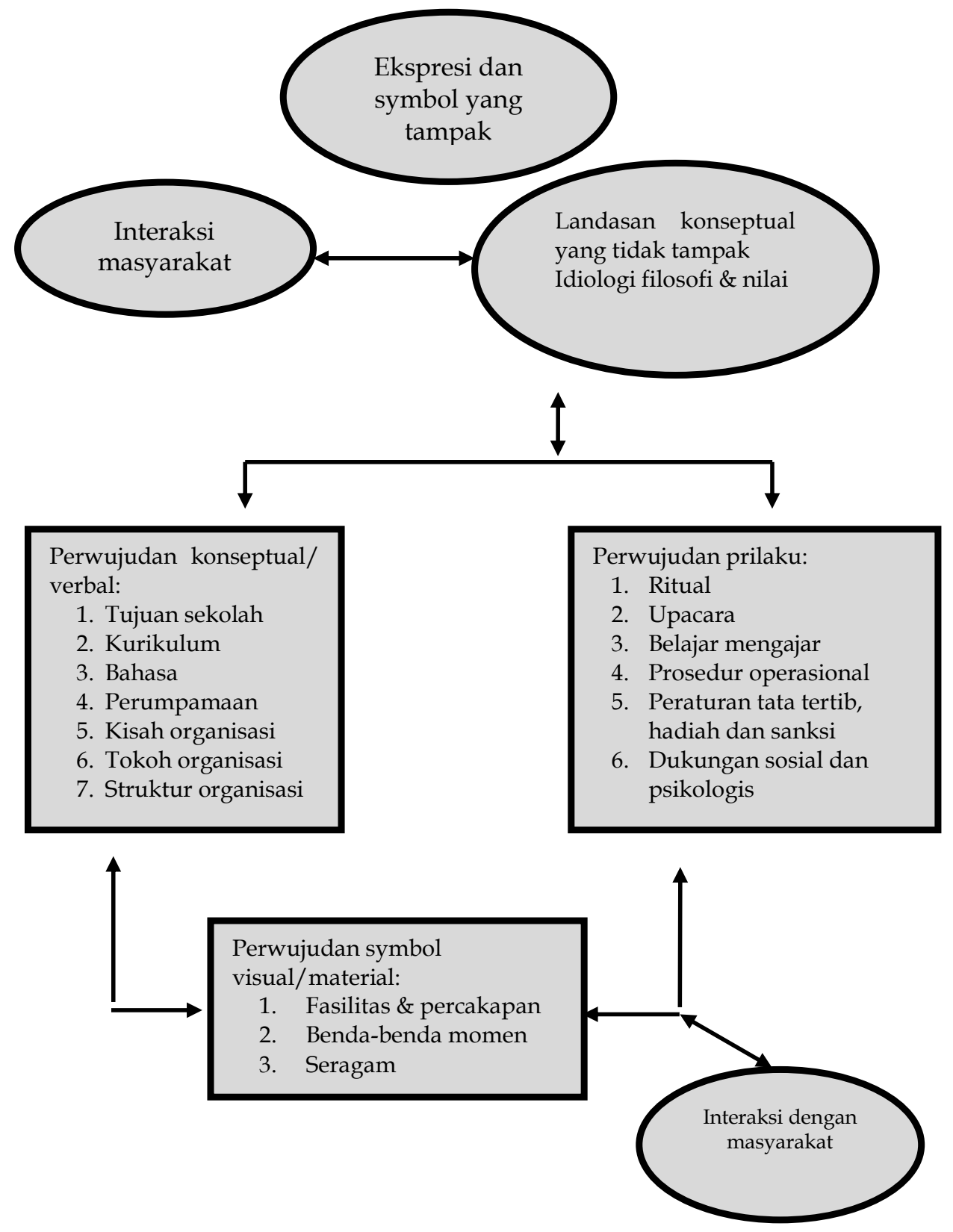

Gambar 2. Unsur Dalam Budaya Organisasi Di Lembaga Pendidikan

Pondok pesantren merupakan lembaga pendidikan agama bagi santri yang mendalami agama atau "ngaji" ilmu agama Islam. Pondok pesantren sebagai lembaga tidak hanya identik dengan makna keislaman, tetapi juga mengandung makna keaslian (indigenous) Indonesia (Nurcholish Madjid, 1997: 3), sebab 
keberadaannya mulai dikenal di bumi Nusantara para periode abad ke 13-17 M dan jawa pada abad ke 15-16 M Mastuhu, 1994: 6).

Pondok pesantren pertama kali didirikan oleh Syekh Maulana Malik Ibrahim atau Syekh Maulana Maghribi (Wahjoetomo, 1997: 70). Atau Sunan Gresik yang dikenal sebagai spiritual father walisongo. Menurut Ronald Alan Lukens Bull (1997: 60), Syekh Maulana Malik Ibrahim mendirikan pondok pesantren di Jawa pada tahun $1399 \mathrm{M}$ untuk menyebarkan Islam di Jawa. Namun dapat dihitung bahwa sedikitnya pondok pesantren telah ada sejak 300-400 tahun lampau. Usianya yang panjang ini membuktikan bahwa pondok pesantren telah memiliki budaya bangsa atau budaya pondok pesantren dalam bidang pendidikan dan telah ikut serta mencerdaskan kehidupan bangsa (Mastuhu, 1994: 7).

Secara faktual perkembangan pondok pesantren di Indonesia bisa dibedakan menjadi tiga bentuk, yaitu; 1) Salaf atau tradisional, 2) Khalaf atau modern, dan 3) Komprehensif atau kombinasi. Pertama, pesantren ini masih mempertahankan bentuk aslinya sebagaimana berlangsung sejak awal kemunculannya dengan semata-mata mengajarkan kitab-kitab (kuning) yang ditulis oleh ulama' klasik dengan menggunakan bahasa Arab. Model pengajarannya bisa berbentuk sorogan maupun bandongan dan jenjang pendidikan tidak berdasarkan tingkatan waktu melainkan dengan selesai atau khatamnya suatu kitab tertentu kemudian santri dapat naik kejenjang berikutnya dengan mempelajari kitab yang tingkat kesulitannya lebih tinggi dan seterusnya. Pendekatan ini sejalan dengan prinsip pendekatan modern yang dikenal dengan sistem belajar tuntas. Dengan cara ini santri dapat lebih intensif mempelajari suatu cabang ilmu. Kedua, pesantren khalaf, pondok pesantren ini menyelenggarakan kegiatan pendidikan dengan pendekatan modern melalui kegiatan formal, baik madrasah (MI, MTs, MA), maupun sekolah (SD, SMP, SMA, SMK) atau nama lainnya tetapi dengan pendekatan klasikan (jenjang kelas) dengan satuan program didasarkan pada satuan waktu. Pengajaran kitab-kitab Islam klasik tidak diselenggaran. Sekalipun bahasa Arab diajarkan, namun penguasaannya tidak diarahkan untuk memahami bahasa Arab yang terdapat dalam kitab-kitab klasik. Penguasaan bahasa Arab dan Inggis cenderung ditujukanuntuk kepentingan-kepentingan praktis. Ketiga, pesantren komprehensif atau kombinasi, pondok pesantren menyelenggarakan pendidikan secara komprehensif karena memadukan sistem pendidikan dan pengajaran gabungan antara tradisional dan modern dengan kurikulum lengkap. 
Budaya pondok pesantren paling tidak memiliki lima elemen dasar, yakni pondok, masjid, santri, pengajaran kitab-kitab Islam klasik, kiai (Dhofier, 1982: 44). Menurut Martin Van Bruinessen (1995: 17), salah satu budaya atau tradisi agung (great tradition) di Indonesia adalah tradisi pengajaran agama Islam yang bertujuan untuk mentransmisikan Islam Tradisional sebagaimana yang terdapat dalam kitab-kitab klasik yang ditulis berabad-abad yang lalu.

Pondok pesantren tradisional atau modern yang mengajarkan keislaman diselenggarakan dalam bentuk asrama yang merupakan komunitas sendiri di bawah kepemimpinan kiai sebagai manajer puncak, dibantu oleh seorang atau beberapa orang ulama dan para ustadz yang hidup bersama ditengah-tengah para santri dengan masjid atau surau sebagi pusat kegiatan peribadatan keagamaan, gedung sekolah atau ruang-ruang belajar mengajar serta pondok sebagai tempat tinggal santri (Mastuhu, 1994: 6). Budaya organisasi dalam upaya memelihara tata nilai yang menekankan ibadah dan penghormatan kepada guru atau ustadz sebagai jalan memperoleh ilmu pengetahuan agama yang hakiki. Tata nilai yang dianut dan didukung dalam kehidupan pondok pesantren diantaranya adalah konsep Ahlussunnah Wal Jamaah. Istilah ini menunjukkan pada paham yang paling menguasai keseluruhan rasa pengendalian diri (sense of identity) orang-orang pondok pesantren dan selalu menjadi jawaban atas pertanyaan-pertanyaan mengenai golongan atau sistem nilai apa yang dianut (Sudjoko, dkk, 1994: 30-31). Yang kemudian menjadi sebuah perilaku organisasi bagi orang-orang (steakholder) yang berada dalam wilayah pondok pesantren yang kemudian menjadi budaya pondok pesantren.

Pola kehidupan interaktif dalam pondok pesantren terjalin diantara kiai, ustadz dan santri. Pola ini mencerminkan pengalaman keagamaan yang dibangun dari nilai-nilai kitab-kitab klasik atau kuning. Komunitas ini lebih lanjut dinamakan lembaga yang memiliki tradisi, kelakuan, norma, atau kaidah hukum. Hal ini berimplikasi pada istilah lembaga yang merupakan kumpulan dari berbagai cara berperilaku yang diakui oleh anggota masyarakat sebagai sarana untuk mengatur hubungan-hubungan sosial. Dengan pola hubungan sosial pondok pesantren seperti ini individu mempunyai kedudukan dan peranan tertentu didalam hubungan sosial sebagai suatu bentuk pergaulan hidup (Abdulsyani, 1994: 76).

\section{Budaya Organisasi Pesantren yang Ramah Ekologi}

Kitab-kitab yang diajarkan di pesantren meliputi al-Qur'an, al-Hadits, Fiqh, Bahasa, Akhlaq, Tasawuf, Tafsir, dan beberapa cabang ilmu yang lain dalam 
catatan Martin Van Bruenessen (1994: 142-164) berjumlah ratusan. Secara umum, kitab yang diajarkan di pesantren dalam catatan Marhumah (2011: 142-164) yang meneliti di pesantren Krapyak, baik di Al-Munawwir maupun Ali Maksum, umumnya adalah kitab-kitab klasik yang dikarang oleh para ulama zaman lampau (abad pertengahan).

Mengadopsi Emma yang menggambarkan konstruksi Sosial Gender di Pesantren, artikel ini melihat persoalan lingkungan dalam pesantren dapat dianalisis melalui muatan pesan-pesan ramah lingkungan yang beredar dalam proses sosialisasi yang berlangsung di pesantren. Ajaran Islam yang mendapat tekanan dalam diskursus lingkungan di pesantren dan melihat pesan-pesan ramah lingkungan yang diartikulasikan oleh para agen sosialisasi.

Bagan berikut tentang proses sosialisasi ramah lingkungan yang berlangsung di pesantren:

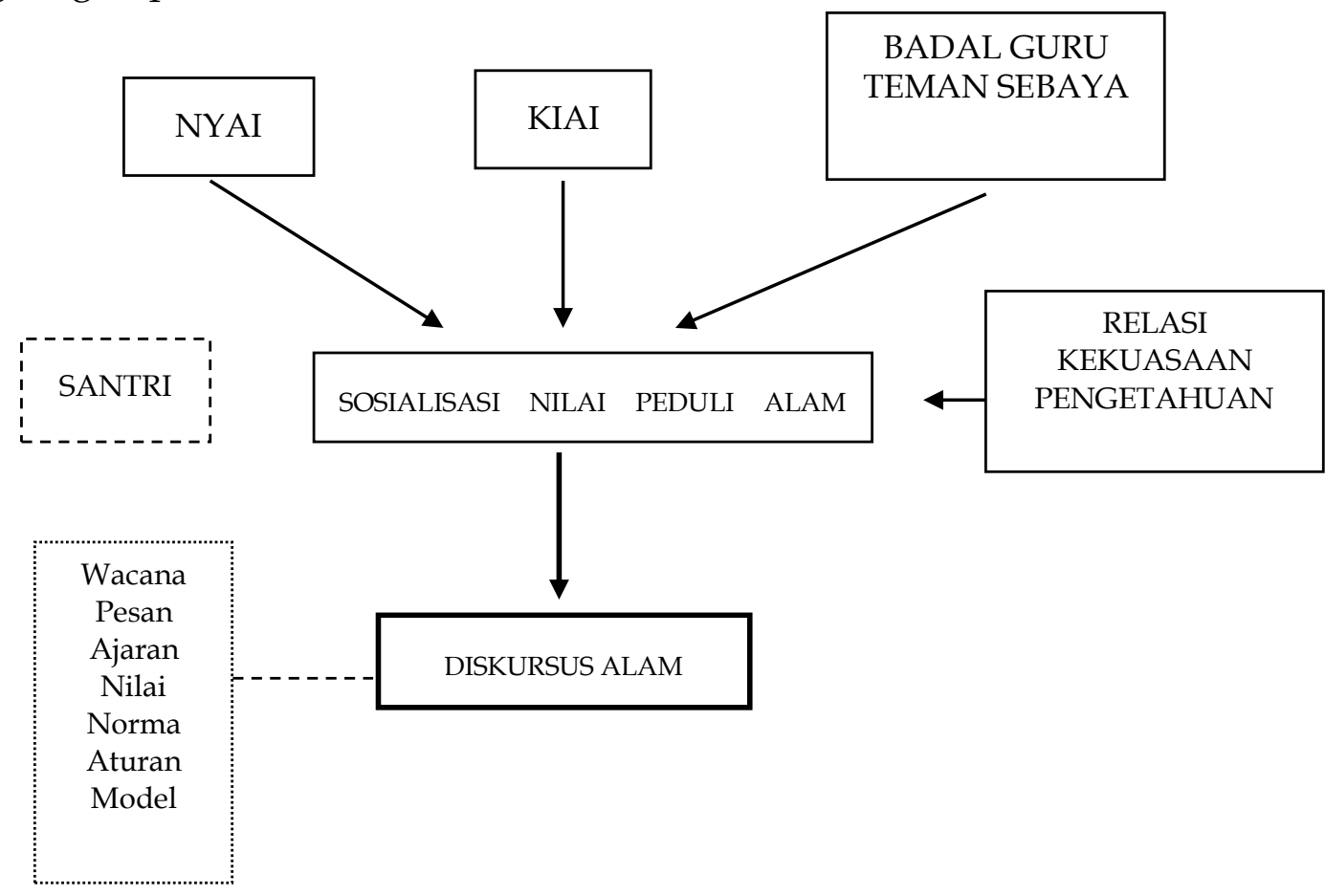

Gambar 3. Proses Sosialisasi Nilai Peduli Lingkungan Di Pesantren

Pembentukan budaya organisasi dalam pesantren yang peduli lingkungan, mendapatkan sumber dari ajaran Islam sebagai tata nilai. Santri baik putra maupun putri diharapkan memiliki kesadaran yang sama dalam perilaku ramah lingkungan. Keterlibatan aktif santri baik putra maupun putri ini dijiwai oleh semangat al-Qur'an Surat al-Ahzab ayat 35; 


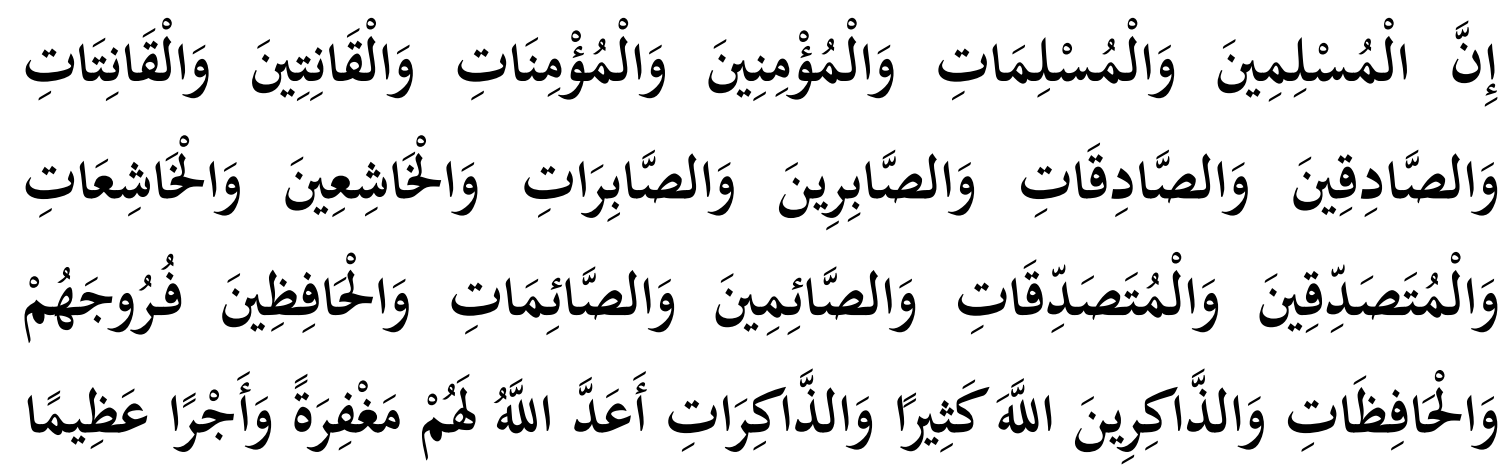

Artinya:

"Sesungguhnya laki-laki dan perempuan yang muslim, laki-laki dan perempuan yang mukmin, laki-laki dan perempuan yang tetap dalam ketaatannya, laki-laki dan perempuan yang benar, laki-laki dan perempuan yang sabar, laki-laki dan perempuan yang khusyuk, laki-laki dan perempuan yang bersedekah, laki-laki dan perempuan yang berpuasa, laki-laki dan perempuan yang memelihara kehormatannya, laki-laki dan perempuan yang banyak menyebut (nama) Allah, Allah Telah menyediakan untuk mereka ampunan dan pahala yang besar."

Dalam ayat ini, baik laki-laki dan perempuan digambarkan dapat menjadi sosok seorang muslim, mukmin, yang taat, benar, sabar, khusu', bersedekah, berpuasa, memelihara kehormatan, serta senantiasa mengingat Allah SWT dalam seluruh aktifitas keduanya. Oleh sebab itu, keduanya berhak untuk mendapatkan ganjaran berupa berupa ampunan dan pahala dari Allah SWT. Penyebutan secara bersamaan dari kedua jenis manusia, laki-laki dan perempuan pada ayat diatas, menjelaskan tentang hubungan harmonis manusia kepada Tuhan, kemudian kepada sesama saudara mereka yaitu manusia. Ayat ini menjelaskan bahwa tanpa ada perbedaan, manusia memiliki potensi dan kesempatan yang sama dalam melaksanakan ajaran agama (Febriani, 2015: 150).

Perbuatan tangan manusia yang mengakibatkan kerusakan adalah sebagai bentuk aktifitas merusak yang dijelaskan dalam bentuk umum bagi manusia. Oleh karena sebab itu, dapat dipahami bahwa kedua jenis manusia memiliki potensi yang sama dalam berbuat kerusakan. Pada Q.S al-Ruum: 14 yang artinya

"Telah nampak kerusakan didarat dan dilaut disebabkan karena perbuatan tangan manusia, supaya Allah merasakan kepada mereka sebagian dari (akibat) perbuatan mereka, agar mereka kembali (ke jalan yang benar)". 
Ayat ini secara emplisit menolak anggapan ekofeminis tentang kerusakan lingkungan yang memiliki korelasi dengan sikap dominatif dan eksploitatif yang dititik beratkan hanya kepada laki-laki (Febriani, 2015: 151).

Upaya untuk menjaga lingkungan, dalam pengalaman seorang muslim tidak hanya berkaitan dengan hal yang sifatnya profan, melainkan terkait dengan hal yang sakral dan persoalan keagamaan. Kh Abdul Basith di Pesantren al-Nuqayyah Madura membuat hutan dilandasi dengan pemahaman bahwa hutan diperlukan untuk kesempurnaan shalat. Shalat yang sempurna diawali dengan wudhu yang sempurna. Wudhu yang sempurna memerlukan air yang cukup. Air yang cukup membutuhkan aliran sungai yang meniscayakan adanya mata air dan hutan. Model pendidikan Islam berbasis ekologi belum masuk dalam rumusan materi dan kurikulum dalam pendidikan pesantren. Pengembangan model pendidikan Islam berbasis ekologis, bisa diwujudkan dalam fikih lingkungan (fighul bi'ah), yaitu dengan menerjemahkan term-term kajian fikih yang murni dalam bingkai ekologis. Nilai-nilai atau seruan untuk melestarikan lingkungan hidup banyak sekali di temukan baik dalam alQur'an, hadits, ataupun dalam formulasi fikih. Konsep yang telah mapan dalam fikih dan dipelajari para santri misalnya ihyaul mawat (menanami tanah yang tak digunakan. Dalam implementasinya, konsep ini bisa diwujudkan dengan bercocok tanam baik berupa persawahan, pertambakan, dan atau perkebunan yang terkait dengan persoalan ekologi yang banyak dipraktekkan oleh pesantren. Dalam kajian fikih, jika ditinjau dalam perspektif pembahasan ekologis thaharah, hima, ihyaul mawat. Konten kajian dari ketiga term tersebut, lebih lanjut jika di interpretasikan dalam konteks kekinian, maka akan menghasilkan bentuk fikih lingkungan (fiqhul bi'ah). Pengolahan lahan bagi pesantren sebagai implementasi nilai-nilai ekologis banyak dijumpai. misalnya, di pesantren al-Isti'anah Pati santri bertanam di lahan persawahan milik pesantten. Di banyak pesantren, telah menjadi satu kebiasaan bagi santri yang khidmah (ngabdi dalem) diberikan lahan untuk dikelola berupa tambak, ternak sapi, ayam petelor dan lainnya. Di pesantren Manbaus Sholihin Gresik, kotoran sapi-sapi tersebut di kelola menjadi biogas untuk dijadikan bahan bakar memasak sejak tahun 2009.

Jika beberapa kegiatan di atas, tidak selalu melibatkan seluruh santri maka pesantren memiliki bentuk nyata kegiatan cinta lingkungan yang disebut dengan "ro'an" atau kerja bakti. Kerja Bakti bersih lingkungan ini biasanya berupa kegiatan membersihkan kamar, dan lingkungan pesantren ini secara rutin yang biasanya di laksanakan seminggu sekali sesuai agenda masing-masing 
pesantren. Selain ro'an yang dilakukan seminggu sekali, pesantren juga melakukan kegiatan piket harian untuk kebersihan kamar dan lingkungan sekitar teutama untuk menjaga kesucian dan kebersihan kamar mandi, tempat wudlu, dan MCK yang dilaksanakan secara bergiliran.

Model klasik pendidikan Islam berbasis ekologis ini, penerapannya dilakukan dengan pembiasaan tradisi yang di bangun semenjak dulu, misalnya tradisi ro'an (kerja bakti). Sebagai kegiatan yang telah terjadwal oleh lembaga, maka kegiatan ini belum sepenuhnya menjadi internalisasi kesadaran personal pada setiap santri. Penanaman kesadaran dan kecintaan terhadap lingkungan hidup bagi santri perlu diintensifkan baik dalam bentuk, muatan dan intensitas waktu sehingga menjadi watak pribadi misalnya dengan melakukan kegiatan pengelolaan lingkungan hidup seperti pemilahan sampah, pembuatan pupuk kompos, pembuatan biopori, penggunaan lampu hemat listrik dan lainnya.

Keterlibatan santri putri dalam kegiatan pesantren dalam kegiatan pengelolaan lingkungan tergolong baik ditandai dengan tingkat partisipasi santri dalam beberapa kegiatan kebersihan lingkungan, pemilahan sampah dan pembuatan kompos. Hanya saja dalam budaya pesantren, ditemukan adanya beberapa kegiatan yang dipandang sebagai area santri putra yang lebih banyak melibatkan santri putra daripada santri putri seperti kegiatan penanaman di lahan, kegiatan pembuatan biogas, pertanian hidroponik yang lebih banyak melibatkan santri putra.

Selain memberikan nilai-nilai ekologis bagi santri, Pesantren sebagai lembaga sosial yang mampu menyatu dengan masyarakat baik itu laki-laki dan perempuan mengambil peranan penting dalam upaya pelestarian lingkungan atau ekologi alam. Menurut Kyai Sahal Mahfud dalam fiqih sosialnya bahwa pesantren mampu memainkan perannya dalam masyarakat termasuk disini mensinergikan ilmu dengan alam. Pesantren sebagai lembaga pendidikan keagamaan mempunyai fungsi aganda. Pertama, sebagai lembaga pendidikan yang mampu mengembangkan pengetahuan, penalaran, keterampilan, kepribadian kelompok muda dan merupakan sumber referensi tata nilai Islami bagi masyarakat sekitar. Kedua, sebagai lembaga sosial di pedesaan yang dapat menggerakkan swadaya dan swakarsa masyarakat khususnya dalam melakukan perbaikan lingkungan (Sahal, 2003: 370)

\section{Simpulan}

Unsur budaya organisasi pesantren yang telah dimanfaatkan dalam peningkatan kesadaran ekologi bagi santri putri dilakukan melaui perwujudan verbal dan perwujudan perilaku. Perwujudan verbal dilakukan melalui 
penguatan nilai-nilai ekologi baik dalam kurikulum melalui penerjemahan materi fikih ke dalam ekologi menuju pada figh al-bi'ah . Sementara perwujudan perilaku terlihat dalam kegiatan pengelolaan lingkungan seperti budaya kerja bakti, pemilahan sampah, pembuatan kompos dan lainnya. Budaya organisasi di pesantren dalam mendorong santri putri terlibat dalam pengelolaan lingkungan terkendala oleh adanya semacam pembagian wilayah bagi santri putri dan putra dalam pengelolaan lingkungan sebagai akibat pembakuan peran di pesantren. Selain menggerakkan santri, pesantren diharapkan dapat menjadi sumber referensi tata nilai Islami bagi masyarakat sekitar dan menggerakkan swadaya dan swakarsa masyarakat khususnya dalam melakukan perbaikan lingkungan. 


\section{DAFTAR PUSTAKA}

Abdulsyani. 1994. Sosiologi: Skematika, Teori dan Terapan. Jakarta: Bumi Aksara

Bruinessen, Martin Van. 1995. Kitab Kuning: Pesantren dan Tarekat. Bandung: Mizan

Bull, Ronald Alan Lukens. 1997. A Peaceful Jihad: Javanese Education And Religion Identity Construction. Michigan: Arizona State University

Dhofier, Zamakhsyari. 1982. Tradisi Pesantren: Studi Tentang Pandangan Hidup Kiai. Jakarta: LPSES

Febriani, Nur Arfiyah. 2015. Wawasan Gender dalam Ekologi Alam dan Manusia. Jurnal Ulul Albab Volume 16, No.2

Fremont E. Kast dan J.E. Rozenzweig, 1974. Organization and Management Systems Approach. New York: Mc Graw-Hill

John M. Ivancevich, dkk. 2006. Perilaku Dan Manajemen Organisasi (Organizational Behavior and Management, Seventh Edition), Alih Bahasa Gina Galih. Jakarta: Penerbit Erlangga

Kanafi, Imam. 2008. Metafisika Sufi dan Jender (Studi Atas Pemikiran Suhrawardi Syaikhul Isyraq (Disertasi). Jakarta: UIN syarif Hidayatullah

Kotter dan Heskett. 1997. Corporate Culture and Performance. Alih Bahasa Benyamin Molan. Jakarta : PT Prenhanlindo Simon\& Schuster (Asia)

Madjid. Nurcholish. 1997. Bilik-bilik Pesantren Sebuah Potret Perjalanan, Jakarta: Paramadina

Mahfudh, Sahal. 2003. Nuansa Figh Sosial. Yogyakarta: LkiS

Marhumah, Ema. 2011. Konstruksi Sosial Gender di Pesantren (Studi Kuasa Kiai Atas Wacana Perempuan). Yogyakarta. PT. LKIS Printing Cemerlang

Mastuhu. 1994. Dinamika Sistem Pendidikan Pesantren. Jakarta: INIS

Mohyi, Achmad. 1999. Teori Dan Perilaku Organisasi. Malang: UMM Press

Murata, Sachiko. 1996. The Tao of Islam, Kitab Rujukan Tentang Relasi Gender dan Kosmologi dan Teologi Islam. Bandung: Mizan

Prasodjo, Sudjoko, dkk. 1994. Profil Pesantren. Jakarta: LP3ES

Sorensen, Jesper B. 2002. The Strength of Corporate Culture and the Realibility of Firm Performance. Administrative Science Quarterly. Vol.47, No.1 (Maret)

Suryono, Agus. 2001. Budaya Birokrasi Pelayanan Publik. Jurnal Ilmiah Administrasi Publik. Vol. I, No. 2 (Maret-Agustus)

Wahjoetomo. 1997. Perguruan Tinggi Pesantren. Jakarta: Gema Insani Press 
Halaman ini bukan sengaja untuk dikosongkan 